\title{
Knowledge and Culture in Tourism Organization Management
}

\author{
Ēriks Lingebērziņš, Turiba University
}

\begin{abstract}
In contemporary management studies, significant attention has been devoted to knowledge and knowledge management issues. Although in philosophical studies knowledge related issues are not new, in management studies they are still considered new. International tourism, operating across borders, offers a unique opportunity to analyse a specific type of knowledge and its importance in management. In this article, key principles of intercultural communication are analysed as part of tacit knowledge of international tourism organization, and the importance of integration of intercultural competences into management of international tourism organization is defined.
\end{abstract}

Keywords: international tourism, tourism organization, intercultural knowledge, management

\section{INTRODUCTION}

International tourism, as a highly globalized industry, in recent decades has applied diverse opportunities, proposed by a changing global international tourism business environment. Market and customer profile changes have stimulated the need to analyse more carefully management of international tourism organizations. International tourism provides unique research opportunities related to management issues in general and management of tourism organizations in particular, as well multiple international tourism related disciplines. Contemporary international tourism management deserves comprehensive understanding of cultural knowledge as factors in management. Results of quantitative research demonstrate importance of intercultural competences in management of international tourism organizations and sales of a particular tourism organization product.

\section{KNOWLEDGE IN TOURISM MANAGEMENT}

Knowledge has become a catchword in contemporary management studies and it is often considered a key factor for organization success in producing and selling its products or services. Being a complex issue related to individuals, groups, societies and organizations, it is still considered to be a relatively new discipline. In 2010, Hakson defined a core principle of knowledge-based organization, stating that it is "recognition of knowledge and abilities as crucial for existence of any organization" [1]. Knowledge-based organizations have become core research objects in contemporary management studies, and it can be stated that the assessment of effective operation of production and service organization is directly related to the implementation and use of knowledge. Already several decades ago, in the discussion of management related issues the idea appeared to consider the role of knowledge. In this respect, it is worth mentioning Drucker's contribution to knowledge management. Already in 1967, Peter Drucker focused on importance of information, admitting that it was necessary to reduce costs of information and to recruit middle-level managers since the future of any organization could not be foreseen with only knowledgeable top managers [2].

Content of information, forms of acquiring and using it in an appropriate way have remarkably changed also the forms of internal operation of organizations. Their operation is not adjusted to core values of industrial era, while information itself and ability to use it has become a key challenge of contemporary organizations. Information and communication technologies have created a basis for establishing knowledge society. Since the 1980s, gravity centre of employment has started to shift from manual to clerical [3].

Although the content of required knowledge to be used and operated differs from industry to industry and even from sector to sector, principles of knowledge management, in fact, remain the same. Diversity of knowledge has been among core issues within entire studies of knowledge, and constant emergence of new forms of entrepreneurship through innovation in services and production generates a need to acquire new knowledge.

Although knowledge, in its philosophical understanding, has been examined by classical philosophers, overall human development has encouraged a need to provide new definitions. In the late $1950 \mathrm{~s}$, special attention was devoted to the interpretation of knowledge, and according to Michael Polanyi, who made a great contribution to this field of studies, it was considered that classifying knowledge as clearly explicit knowledge and tacit knowledge should be viewed as outset for further studies [4]. Later on, in order to describe diverse character of knowledge Thomas H. Davenport and Varun Grover used exactly the same concept proposed by Michael Polanyi, emphasizing the advantages of classifying knowledge as explicit and tacit in further research [5]. Classification of knowledge according to its content enabled researchers to develop new approaches to knowledge implementation in other disciplines. Link between knowledge and contemporary studies of management was proposed by Ikurjiro Nonaka, who integrated Polanyi's ideas into management studies, emphasizing exclusive importance of explicit knowledge in Western entrepreneurship [6]. Other authors, for example, T. Davenport and N. Prusak state that "values and beliefs are integral to knowledge, while people with different values see different things in the same situation" [7]. Due to complex nature of knowledge as a complex subject to be analysed in the context of contemporary social sciences, further discussion of knowledge and its management becomes increasingly important in any business organization. When importance of knowledge was defined, a new era appeared in employer-employee relations, through recognition of tacit knowledge as a valuable asset. 
As employees and their knowledge have become the most important asset of any organization, various management theories attempt to formulate strategies and methods related to knowledge management. In an organization, knowledge itself is considered to be information, which is used to carry out organization's activities. This can be information about clients, competitors, products, processes, mistakes and achievements. Purpose of knowledge management is to promote the acquisition of information and growth of knowledge, by applying systematic efforts [8]. In simple terms, the purpose of knowledge management is to ensure that information is delivered to the right people, at the right time, thus improving organization's operation. Instead, Davenport and Prussak indicated the need to have a more complex understanding of knowledge. They emphasised that "in a global economy, knowledge may be a company's competitive advantage" [7]. It is important to increase a number of organizations that operate in the global market, having employees, who are able to operate with their knowledge in global markets.

Although importance of knowledge in the modern society is not questioned any more, currently, it can be noticed that our societies operate parallel in two different economical systems - industrial and knowledge, where industrial societies are characterized by presence of tangible materials, while knowledge systems operate using knowledge, ideas and services that are often not tangible and visible [9]. Process, when an organization transforms into a knowledge organization, consists of three sub-processes, where at the first stage an organization recognizes importance of knowledge, at the second stage organizations share the acquired knowledge and transform it, and finally they recognize the need for creating new knowledge and realize that their present totality of knowledge is not sufficient for valuable presence in global knowledge economy [10]. Overall interest in knowledge is still developing and there is space for new cognitions to be considered.

Among them, especially tacit knowledge occupies a greater role in management processes. This knowledge is increasingly used to stimulate growth of organization competitiveness [11]. Organizational ability to develop a competitive advantage is based on knowledge and, thus, knowledge is considered to be a resource for organization abilities to work efficiently [12]. Need to be able to operate efficiently in global markets, thus maintaining global competitiveness can be a complicated task for any organization, and under such conditions more and more knowledge is required.

Obviously, recognition of importance of knowledge is important; however, simple knowledge, which is not embedded in any further structure of social interactions, is not entirely valuable. Contemporary studies of knowledge and practical implementation of knowledge leads to discussion of intellectual capital. This is considered to be a more comprehensive form of systemized knowledge.

Thomas Stewart has developed a concept of understanding of intellectual capital, where information and knowledge are its basis. He considers that the intellectual capital is "intellectual material, which is constructed by knowledge, information, intellectual property and experience, which supports creation of wealth" [13]. Therefore, those organizations, which operate based on knowledge, and other tacit materials are organizations, which operate based on intellectual capital. By changing understanding of main organization assets, new approaches to organizations have appeared. Intellectual organization or a new organization is one of the most commonly used denominations to this new type of organizations. Their main difference is in a range of assets they hold, and their production outcomes can be described.

For organizations, where a main asset is their intellectual capital, especially important is human capital - employees, who are in the constant process of acquiring and accumulating knowledge. Their productivity is directly related to knowledge they hold and can use [14]. William Miller, sharing this consideration, defines intellectual capital and its importance to knowledge organizations, illustrating that the issue is not related only to patents, copyrights and other forms of intellectual property, but also emphasizes intellectual capital as presence of organization knowledge, experience, relations, discoveries, innovations, market presence and their interaction to environment, in which organizations operate [15].

From an organizational point of view, knowledge is usually composed of three forms: human capital - the origin of ideas, inspiration and innovation, which is part of organization's resources as long as an employee is part of an organization; structural capital - shared knowledge and processes that are important for an organization; and the ratio of capital, which focuses on market knowledge and relations and includes client capital, client relations, branding and networking [16]. This variable may include even further subforms, depending on the structure and specifics of organization and its operation.

Meredith Belbin, examining organizational changes, which occur with the increasing importance of knowledge, and naming them as "new organizations", identifies further areas of change - organizational alternations, cognizance of a manager as a leader, increasing role of culture in organization management and the role of a team in achieving organizational goals [17].

Defining contemporary principles of management, considering the need to manage an organization, which operates on the principles recognizing knowledge as its core asset, Carl Rodriguez identifies new areas of management, naming contemporary management as management, where it is important to recognize generalization of work, increasing capacity of organization's employees, informal control, confidence, employee development and observance of moral standards [18].

For organizations, where knowledge is a primary asset, aims of management principles are changed. Peter Drucker defines three directions for this type of organizations, which also illustrate knowledge-based organizations. These include constant improvement of organization's operation, knowledge implementation learning and learning to create innovations [19]. Achieving these goals becomes an important task that requires management decentralization, and decision-making 
$2013 / 24$

process should be based on the assessment of organization performance, compliance with market demands, technological development and society transformation changing processes, which include a response to business environment changes, demographical situation, and knowledge that discloses new opportunities for innovation [19]. Also management style is changed, and organizations are expected to respond quickly to the proposed opportunities.

Even recognition of knowledge has become widespread in practically all fields of entrepreneurship; it is a service sector, where knowledge and tacit knowledge are most visible. Especially in the service sector, knowledge is important for effective management and business development. International tourism is not an exception and efficient management of a contemporary tourism organization requires diverse and comprehensive knowledge.

International tourism, which historically has emerged as the Western society privilege, has recently been experiencing major changes due to the transformation of emerging markets and the increasing number of international travellers. This requires tourism organizations to constantly supplement their existing knowledge of their core markets and eventual future markets. Among the various industries directly related to knowledge management, international tourism is highly dependent on cultural differences since any international tourism model experiences different cultures through purchase and experience of a tourism product. Tourism organizations can be proud of their knowledge, since international tourists using classical tourism products face not only well-packaged and organized products but also destination products. In this perspective, understanding of cultural differences becomes especially important and is related to various aspects. First of all, it is necessary to mention the quality assessment of tourism products and destination products by international visitors. However, tourism product and destination product quality assessment is very closely linked to successful organization performance and eventual business development. At the same time, tourism organizations, selling their products to their customers, are also expected to understand cultural differences of customers coming from different markets. Understanding of cultural differences may play a crucial role in proper delivery of service, avoiding fake service expectations, which may result in eventual complaints on tourism.

Although culture and tourism are intimately connected, issues of tourism intercultural communication and management in the production of tourism have remained neglected [20]. In the best case, entire discussion of importance of culture in tourism organization limits itself with a discussion about perception of different culture by visitors of a particular destination.

In the situation, when tourism products, and thereby production of tourism products, become unequivocal since involve different discourses and approaches, more complexity will create even more challenges to tourism organizations, which produce them. However, this is exactly the contemporary situation, to which Greaves gives a categorization of tour traveller tribes that in the future will form international tourism business environment, when looking from a customer's perspective. These tribes include active seniors, global clans, cosmopolitan commuters and global executives [21]. Additionally, also cultural differences deserve the right to be respected and appreciated in the production of tourism products. It can be realized, however, only through the comprehensive integration of different knowledge of cultures and their differences.

General shift away from a tangible culture and heritage towards an intangible culture and creativity affects tourism products of all kinds. Tourism product from the built heritage, museums, monuments, beaches and mountains shifts to the image, identity, lifestyles, atmosphere, narratives, creativity and media [22]. This definitely is an advantage for product consumers on the one hand, but it creates a more complex operational field for those in charge of production.

With a clear link between a culture and tourism, which influence each other, cultural studies in tourism become more complex and required. Demand originates in the changing market structure of international tourism through the emergence of new markets and changing structure of the existing core markets of international tourism. Tourism product assessment and cultural factors affecting it are among relatively little explored fields in tourism management studies. International tourism, being completely knowledge-based business, is considered to be an appropriate field to test a particular type of knowledge, playing an important role in international business - knowledge of culture and cultural competences.

\section{INFORMATION PROVISION QUALITY ASSESSMENT}

Importance of knowledge in any organization can be measured in many different ways. The entire process of measurement is rather complicated and differs in each particular case. However, as proposed previously in a literature review, client relations and knowledge to handle them can be considered a field, where knowledge management measurement can be affected. Alternatively, organization's ability to satisfy its customer demands, using its knowledge about markets, clients and their characteristics, can be analysed. International tourism proposes unique opportunities in this research field. Knowledge to maintain customer relations, interact with them and develop new relations is often associated with complex knowledge. Structure of international tourism predicts that the ability and knowledge to communicate, achieving company's goals in the international business environment, where various cultures and languages interact with each other, are among key tasks for those working in this industry. It can be stated that international tourism organization's employees interacting with different cultures in different languages, additionally to their professional knowledge, should also possess a high level of intercultural communication knowledge aiming at understanding the needs of their clients and modelling interaction scenarios with foreign visitors to countries or regions they propose to international visitors.

The aim of this article is to disclose partial results of quantitative research conducted to identify and to assess 
international tourism organization's performance in communication with its customers on a particular product, its specifics. 502 questionnaires were collected and analysed during the tourism season of 2011. In order to verify stability of results, research was also continued in 2012. Questionnaires were distributed through an incoming tour operator, specialized in niche production - offering guaranteed escorted tours. Advantage of choosing this type of an organization is within a fact that diverse programmes are offered for different target markets operating in different languages. Target market groups and languages correspond to a classical division into individualist and collectivist cultures. Thus, it can be considered that research was conducted to verify presence of cultural differences in a particular segment of tourism product. Sales of tourism product are affected through a distribution channel of classical tourism product. Considering communication with customers - wholesale tour operators and travel agencies - communication can be considered a constant process also during the operational period, not only during sales; therefore, improvement in communication may be achieved during a longer period, and more comprehensive conclusions can be made based on a constant observation.

Guests participating in guaranteed escorted tours were asked various questions in order to identify importance of cultural factors in quality assessment of a tourism product. The article demonstrates results of cultural differences according to the questions proposed to travellers:

- Does information provided by a travel agent before the tour correspond to service received during the tour? This question tries to find out, if travel agencies, which often are $2^{\text {nd }}$ or even $3^{\text {rd }}$ intermediaries between the incoming tourism operator and the end client, receive information from tour operators, whose product is purchased, according to information provided by a tour operator. In the survey, this question is marked as Q1.

- Did a tour programme of a travel agent, whose tour was booked, in a catalogue/web-site correspond to the programme received? This question aims to find out, if the programme presented by an incoming tour operator has not been altered while being sold through intermediaries to the end client. Answers to this question also show if through the localisation of programme texts and other materials the information remains appropriate; moreover, the answers allow identifying, if an organization should consider this issues when preparing their product localized versions for customers in different markets. In the survey, this question is marked as Q2.

In both cases, failing to maintain proper information provision from an incoming tour operator, which produces a particular product, to the end client, who goes on a trip, may result in complaints, which can be addressed to all involved intermediaries. Besides, in the international market, dealing with different markets and companies requires a broad and often specific intercultural knowledge and ability to communicate efficiently in different markets.

Formulation of questions and the importance of inquiring company's end customers are motivated by previously conducted research on the assessment of service quality. This has indicated the difference in quality assessment of services equally provided to end clients representing individualist and collectivist cultures. The research was based on data from tourist questionnaires in the season 2009-2010 and summarized below. Similar to the Likert scale, 5 answer options were used in this research. Secondary purpose of including such questions is supported by the need to understand if the information about the product of tourism is properly explained to the company's clients and if the company's sales and operational employees require further knowledge and skills in selling and promoting the product.

However, there is a major limitation, given that the provision of information occurs while the organization's employees interact with the organization's customers and their employees. This process of interaction involves several variables, which may influence the result in the information transition period in a positive and negative way. Communication among people is a complex process that involves not only pure transfer of information. Personal communication and interaction skills, as well as knowledge and competences of cultural differences may play an important role.

The issue about importance of competent managers, who are able to represent company's interest in global markets, is related to geocentricity. Geocentricity as an approach to international business relations plays an important role, and the geocentric approach to international business transactions requires negotiators to have knowledge about themselves and the other party in terms of culture, subculture, language and communication style [23]. In international tourism, the geocentric approach confirms importance of knowledge in the enterprise. Even more, considering the character of tourism business, knowledge about cultures and their differences may have a great impact on organization's success in developing stable business contacts with the existing and future customers, by respecting their cultural uniqueness. Geocentricity, as a comprehensive approach in dealing with international markets, proposes a rather clear understanding of importance of culture-based knowledge in management and customer relations.

TABLE 1

Quality Assessment (2009)

\begin{tabular}{|l|l|l|}
\hline & \multicolumn{1}{|c|}{ English/German } & Italian/Spanish \\
\hline $\begin{array}{l}\text { Hotel service (overall } \\
\text { evaluation) }\end{array}$ & 3.81 & 3.75 \\
\hline $\begin{array}{l}\text { Breakfast service at a } \\
\text { hotel }\end{array}$ & 3.81 & 3.86 \\
\hline $\begin{array}{l}\text { Dinner service at a } \\
\text { hotel }\end{array}$ & 3.76 & 3.78 \\
\hline $\begin{array}{l}\text { Optional excursions } \\
\text { offered }\end{array}$ & 3.49 & 3.90 \\
\hline Local guide service & 4.05 & 4.03 \\
\hline Tour escort service & 3.80 & 4.05 \\
\hline Transportation services & 4.28 & 3.80 \\
\hline
\end{tabular}


TABLE 2

Quality Assessment (2010)

\begin{tabular}{|l|l|l|}
\hline & \multicolumn{1}{|c|}{ English/German } & Italian/Spanish \\
\hline $\begin{array}{l}\text { Hotel service (overall } \\
\text { evaluation) }\end{array}$ & 3.80 & 3.76 \\
\hline $\begin{array}{l}\text { Breakfast service at a } \\
\text { hotel }\end{array}$ & 3.84 & 3.86 \\
\hline $\begin{array}{l}\text { Dinner service at a } \\
\text { hotel }\end{array}$ & 3.72 & 3.76 \\
\hline $\begin{array}{l}\text { Optional excursions } \\
\text { offered }\end{array}$ & 3.59 & 3.80 \\
\hline Local guide service & 4.06 & 4.02 \\
\hline Tour escort service & 3.70 & 4.02 \\
\hline Transportation services & 4.26 & 3.60 \\
\hline
\end{tabular}

According to the Likert scale, for both questions 5 answer options have been proposed, ranging from 'completely' to 'do not correspond'. Taking into account the differences of visitors, questionnaires were made and distributed in 5 languages according to core markets of a particular product. Totally, 2,160 questionnaires were distributed among guests from 22 different countries. Hoofstede's model of cultural differences was taken as a basis for the analysis of differences originating from cultural factors. For the further analysis, results were limited, and 4 countries in each group were chosen, where a majority of clients came from. Choosing 4 countries in each block resulted in 449 valid questionnaires to be analysed, representing $21 \%$ of total distributed questionnaires. In the first group, 252 were considered valid, and in the second group - 197 questionnaires. The countries to be analysed were grouped into the individualist and collectivist culture groups.

In the analysis of culture and elements, different societies distinguish two cultural types in their cultures, based on psychological studies and studies focusing on individual relationship to a group [24], naming them individualist and collectivist cultures [25]. If we are to understand the way culture relates to social psychological phenomena, we must analyse it by determining dimensions of cultural variation. One of the most promising dimensions is individualismcollectivism [24]. Individualist cultures are represented by such countries as the USA, Canada, and the European countries, for example, the United Kingdom, Germany, Scandinavia, also by Australia and New Zealand. These cultures describe a system, where individual goals are primary versus collectivist ones.

Collectivist cultures are represented by Japan, China, Korea, India, the African countries, Mediterranean countries, Middle East, Central and South American countries (Brazil, Argentina). In these cultures, goals of individuals are subordinated to a group; studies of collectivist cultures demonstrate how important it is to consider one's own interaction with an entire group [26].

Alternative approach could have been used, grouping the chosen markets into high context and low context communication cultures. However, as part of research was continuation of previous service quality assessment, the need for using these data was noted.
To achieve the set goals of research, all given responses were given the 1-5 range, where 5 means completely, 4 mostly, 3 - partly, 2 - hardly and 1 - do not correspond. All collected questionnaires were grouped according to a participant's country of origin, and 4 countries in each group were chosen to identify eventual differences or similarities. Average score for all given answers was calculated, first for each represented country and finally for the entire group.

TABLE 3

RESULTS

\begin{tabular}{|l|l|l|}
\hline \multicolumn{2}{|l|}{ Individualist culture markets $(\mathrm{n}=252)$} & Q1 \\
\hline & 4.408 & 4.618 \\
\hline Germany & 4.607 & 4.714 \\
\hline The Netherlands & 4.408 & 4.580 \\
\hline Australia & 4.500 & 4.556 \\
\hline The USA & 4.481 & $\underline{4.617}$ \\
\hline & & \\
\hline Collectivist culture markets (n=197) & & Q2 \\
\hline & Q1 & 4.637 \\
\hline Spain & 4.402 & 4.696 \\
\hline Italy & 4.442 & 4.840 \\
\hline Brazil & 4.741 & 4.600 \\
\hline Portugal & 4.519 & $\underline{4.693}$ \\
\hline & 4.526 & \\
\hline
\end{tabular}

The achieved results, as illustrated above, demonstrate the existence of slight displacement, confirming that presence of various intermediaries in the product sales process of tourism organization, results in bias of information and creates slightly misleading information to guests. Although it is comparably little, it still confirms an assumption that communication process and professional information transfer need to be considered. Besides, it shows that in different countries results differ and also total difference of both market groups shows minor differences.

Even the majority of returned questionnaires illustrated that overall information transition in a particular case was successful: there were 44 questionnaires returned, where information provided by a travel agent and its compliance with the received service was ranked between 3 and 1.13 participants out of 44 were guests from Germany, 7 - from Argentina, 7 - from Belgium, while others were from different countries. In the second question, there were 16 questionnaires which were returned with answers receiving between 3 and 1 point. 5 of them were from guests from Germany, 3 from Italy and 3 from New Zealand. This indicated that individualist cultures represented a higher number of guests affected by miscommunication between an incoming tour operator and a travel agency in their travel purchase process. As the number of low rated questionnaires was below $1 \%$, they were considered not to demonstrate a general trend, but obviously required analysing particular markets in the future. 
The obtained results of quantitative research sufficiently contributed to further research, supporting the need to understand the origin of differences and the importance of intercultural communication in management of an international tourism organization in general and in sales of tourism product in particular. The results demonstrated differences in the perception and understanding of the tourism product. Thus, it is necessary to respect intercultural competence as a crucial knowledge in management of international tourism organization.

\section{CONCLUSION}

Knowledge still remains as a rather unknown variable in the organization management and related studies. Especially in industries, operation of which is entirely based on knowledge and knowledge management, knowledge remains a slightly examined variable, which has a great impact on operational results of an organization. Knowledge-based organizations are associated with intellectual resources they hold through their employees, who are considered a main asset of a contemporary organization. Focusing on a specific industry tourism, research has aimed to disclose the existence of specific field of knowledge - recognition of cultural differences in a tourism organization.

The obtained results illustrate the importance of intercultural competence as well as recognize the need to respect it in the management of an international tourism organization. At the same time, they clearly indicate the need to further analyse factors influencing operational results of an international tourism organization that deals with international guests from different countries with diverse cultural backgrounds. As research results indicate the information loss in a communication chain between an incoming tour operator and an end traveller through a chain of tourism organization product sales, it is required to proceed with further analysis of these data, analysing such processes as product adaptation, translation and localization, before the reaches an end customer. In-depth interviews with direct clients of an incoming tour operator (product managers and sales managers) will be needed. This will allow focusing on organization's employees in general and their market knowledge, language skills and respect of particular cultural differences in product promotion and sales in particular.

\section{REFERENCES}

[1] L. Hakson, "The firm as an epistemic community: the knowledge based view revisited", Industrial and Corporative Change. Vol.19, No.6, 2010 pp.1801-1828. http://dx.doi.org/10.1093/icc/dtq052

[2] P. Drucker, "The Manager and the Moron", McKinsey Quarterly. Spring 1967, Vol. 3, Issue 4, pp. 42.-50.

[3] P.Drucker, "The Coming of the New Organization", Harward Business Review, January-February 1988, pp. 1.-19.

[4] R.M. Grant, “ Toward a Knowledge-Based Theory of The Firm” Strategic Management JournaL, Vol. 17, 1996, pp.109.-122.

[5] T. Davenport, V. Grover, "General Perspectives on Knowledge Management: Fostering a Research Agenda", Journal of Management Information Systems. Vol.18, No.1, 2001. pp.5.-21.
[6] I. Nonaka, The Knowledge Creating Company, Harward Business Review, November-December 1991, pp. 96-104

[7] H.Davenport and L. Prusak, "Working Knowledge". Harward BusinessSchool Press, 1998

[8] C. O'Dell, C. Hubert, The New Edge in Knowledge, APQC: 2011

[9] M. Adams, "Management 2.0: managing the growing intangible side of your business", Business Strategy Series, Vol. 9, No 4, 2008, pp. 190.200 .

[10] S. Kumar, G. Thondikulam, “ Knowledge management in a collaborative business network", Information Knowledge Systems Managemen,. Vol. 5, 2005, pp. 171.-187.

[11] G.A.Beesley, C.Cooper, "Defining knowledge managemenet (KM) activities: towards consensus", Journal of Knowledge Management, Vol.12., 2008, pp. 48.-62.

[12] B. Marr, G.Schiuma, A.Neely, Intellectual capital - defining key performance indicators for organizational knowledge assets" Business Process Management, Vol.10, No.5. 2004, pp. 551.-569.

[13] M. Ahlgren "What is Intellectual Capital?", UNLV Gaming Research \& Review Journal, Vol. 15, Issue 2, 2011, pp. 17.-21.

[14] M. Nishikawa, "(Re)defining Care Workers as Knowledge Workers" Gender, Work \& Organization, Vol.18., Issue 1., 2011, pp. 113.-136.

[15] W. Miller, "Building The Ultimate Resource", Management Review January, 1999. pp. 42.-45.

[16] N.Bontis, W.C.Keow, S.Richardson, "Intellectual capital and business preformance in Malaysan industries", Journal of Intellectual Capital. Vol.1, No.1, 2000, pp.85.-100.

[17] M. Belbins, Jaunās Organizācijas. Lietišksās Informācijas Dienests: Rīga 2009.

[18] C.A. Rodrigues, "Fayol's 14 principles of management then and now: a framework for managing today's organizations effectively", Management Decision. Vol.39, Issue 10, 2001, pp. 880.-889.

[19] P.Drucker, "The New Society of Organizations", Harward Business Review. September-October 1992, pp. 95.-104.

[20] N. Scherle, T.Coles, "International business networks and intercultural communications in the production of tourism". In T. Coles and M.C. Hall (Eds.), International Business and Tourism: Global Issues, Contemporary Interactions, New York: Routledge. 2008, pp. 124.142.

[21] D. Greaves, "Customer Segmentation Traverller Types and Their Needs in 2020". In R. Conrady, M. Buck (Eds.), Trends and Issues in Global Tourism, Berlin: Springer 2008, pp. 149.-164.

[22] G.Richards, J.Wilson, "Creativities in tourism development". In G. Richards J.Wilson (Eds.), Tourism, Creativity and Development, New York: Routledge 2007, pp. 255.-289.

[23] J. Rudd, D. Lawson, Communicating in Global Business Negotiations:Geocentric Approach, Sage Publications, 2007.

[24] T. H. Triandis, R. Bontempo, J. M. Villareal, "Individualistm and Collectivism: Corss-Cultural Perspectives on Self-Ingroup Relationships" in Journal of Personality and Social Psychology, Vol. 54, 1988, pp. 323-338. http://dx.doi.org/10.1037/0022-3514.54.2.323

[25] J., A. Goncalo, B., M. Staw, "Individualism-collectivism and group creativity", Organizational behaviour and Human Decission Processes, Vol. 100, 2006, pp. 96.-109.

[26] S.H. Watkins, R.Liu, "Collectivism, Individualism and In-Group Membership: Implications for Consumer Complaining Behaviors in Multicultural Contexts" In: Manrai, L.A., Manrai, A.K. (Eds.), GlobalPerspectives in Cross-Cultural and Cross-National Consumer Research, New York: International Business Press, 1996, pp. 69.-96.

Eriks Lingeberzins is a third year doctoral student at the Turiba University, Riga, Latvia and currently elaborates a doctoral thesis in business administration on the issue related to disclosing aspects of intercultural communication in international tourism business management.

Professionally, he is involved in management of inbound tour operator in the Baltic Sea region "Via Hansa Hospitality Collection" and is responsible for individual traveller business development and works as a Managing Director of group company "Balticvision Riga". He is a Lecturer at the Turiba University. 
$2013 / 24$

Ēriks Lingebērziṇš. Zināšanas un kultūra tūrisma organizācijas vadīšanā

Zināšanu atzī̌sana par vērtīgu uzṇēmumu aktīvu, kurš turklāt pieder organizācijas darbiniekiem, ir sekmējusi jaunu pieeju vadībzinātnē, kur galvenā uzmanība pievērsta netaustāmiem organizācijas aktīviem. Lai gan zināšanas jau izsenis ir bijušas filozofijas viens no galvenajiem intereses objektiem, zināšanu nozīme vadībzinātnē pētīta salīdzinoši nesen. Zināšanu specifiskais raksturs nosaka izpētes sarežǵîtību un neviennozīmību, nemot vērā katrai nozarei raksturīgās specifiskās, unikālās zināšanas. Starptautiskā tūrisma vide, kurā ļoti būtiska ir spēja strādāt globālā, starpkultūru vidē, ir interesants izpētes objekts, analizējot specifisku - kultūras zināšanu nozīmi tūrisma uzņēmējdarbībā. Rakstā atspoguḷota daḷa plašāka pētījuma, kura mērḳis ir definēt kultūras atšḳirību nozīmi starptautiska tūrisma uzñēmuma vadīšanā. Rakstā atspoguḷoti kvantitatīvā pētījuma rezultāti, kuri papildina iepriekš veiktu pētījumu, lai identificētu starpkultūru komunikācijas procesa rezultātu tūrisma organizācijas produkta pārdošanā, nosakot, vai gala patērētājiem sniegtā informācija, ceḷojumu iegādājoties, atbilst paredzētajai. Pētījuma rezultāti atklāj starpkultūru kompetenču nozīmi starptautiska tūrisma uznēmuma vadīšanā, vienlaikus norādot uz nepieciešamību veikt tālākus pētījumus par starptautiska tūrisma uzṇēmuma darbinieku zināšanām un prasmēm, strādājot starptautiskā tūrisma uzņēmumā, kurš darbojas starpkultūru vidē, nosakot darbinieku lomu efektīvas starpkultūru komunikācijas nodrošināšanā tūrisma organizācijas produkta pārdošanā.

Эрик Лингеберзиньш. Знания и культура в менеджменте туристической организации

Признание знаний ценным корпоративным активом, которым, кроме того, владеет персонал организации, способствовал новый подход к управлению, который фокусируется на нематериальные активы организации. Хотя знания уже давно являются важным объектом интереса в философии, роль знаний в области управления наукой изучены сравнительно недавно. Специфический характер знаний обуславливает неоднозначность и сложность в исследовании. Среда международного туризма, в которой важна способность работать в глобальной и кросс-культурной среде, является интересным объектом исследования на основе анализа культурно-специфических знаний в туристическом бизнесе. В статье показана часть более широкого исследования, направленного на определение роли культурных различий в управлении международного туристического предприятия. В статье описываются результаты исследования, которые дополняют предыдущие исследования, с целью выявления результатов межкультурной коммуникации туристической организации по сбыту продукции, определяя, соостветствует ли переданная покупателю информация той, которая изначально была предназначена. Результаты исследования показывают значение межкультурных компетенций в менеджменте международного туристического предприятия, одновременно указывая на необходимость дальнейших исследований в области знаний и навыков сотрудников таких предприятий, которые работают в кросс-культурной среде, определяя роль сотрудников в обеспечение эффективной межкультурной коммуникации в процессе продажи продуктов. 